\title{
A noite é vertigem 1
}

Onde começa a cena e termina a rua? Esse bairro existe? Onde é que riscamos sua fronteira e começa a memória de alto risco? Será nesse corte silencioso de um tecido vermelho, em que Dibuk, o espírito maligno hebraico, vem anexar-se, noturno, em carne e sangue, aos manequins que testemunham, mudos, a orquestra das máquinas de costura de bolivianas insones-sonhadoras?

Ouve-se, vindo do além-muro de tijolos, o som de trem passando. Mas não é o de um trem real, esse ruído que se cruza com a fala da noiva abandonada vagando pela alta marquise (na atuação excelente de Raquel Morales), depois com a do cracômano, extravagante entre esgoto e escada de ferro escalada até o muro da linha férrea (Roberto Audio). O som foi gravado e se projeta no muro, a iluminação jogando, como sempre, ao lado do design sonoro, papel estratégico na condução da narrativa desse Bom Retiro 958 metros. A locutora da Rádio Infinita (Sofia Boito) anuncia um desastre iminente, numa transmissão amalucada, dando notícia de que "o espetáculo é o guardião do sono".

Encenada pelo Teatro da Vertigem ao se completarem seus 20 anos de trabalho, dos mais inovadores em qualquer ângulo mirado na cena dramática contemporânea brasileira, a montagem já mereceria ser saudada pelo que carrega de esforço de pesquisa e trabalho coletivo, em condições adversas. Mas dizer isso é pouco. Se há um núcleo de sentido persistente ao longo dessa trajetória, que pode servir de elo à história do Vertigem, ele se refere aos aspectos da ilusão estruturante do contemporâneo, das fantasmagorias que a senda do progresso cravou na vida da cidade e das multidões. Que cedo aprenderam o duro ditame do estranhamento de si e dos outros como lei maior da urbe.

\footnotetext{
${ }^{1}$ Artigo publicado em O Estado de S.Paulo, 22 de julho de 2012, p. J8 
Saga imigrante. Pois o itinerário labiríntico desses quase mil metros a que nos convida Bom Retiro não é o de um delírio místico, redenção messiânica ou comédia estereotipada de costumes, como se vê no teatro praticado por aí. A vertigem é a do reino das mercadorias e seus sucessivos fetiches. "Dopping Center" diz o cartaz no fundo de um corredor do shopping, no início da peça. A vertigem é a saga de tantas etnias de imigrantes - italianos, judeus, gregos, árabes, coreanos, bolivianos -, de sua esperança ao desconsolo, de suas memórias ao esquecimento, de cada saga grupal ou familiar ao abandono do tempo nas dobraduras do espaço de um bairro central e periférico, a um só tempo febril, violento, degradado, riquíssimo, paupérrimo, cheio e vazio.

A vertigem é essa arqueologia trôpega de destinos abissais e sua síntese numa teatralização que, no que nos oferece o bairro, poderia se achar quase impossível. Vertigem de todas as boas memórias, agora batendo em retirada. Bom Retiro das confecções invisíveis e dos imigrantes-retirantes. Dos manequins mortos e da manequim viva, a bela atriz Káthia Bissoli, que ostenta cartazes com descontos crescentes e cinicamente proporcionais ao avanço de sua nudez. Vertigem nos olhos atônitos desses coreanos apressados nos carrões e nos pedestres bolivianos que passam furtivos e não sabem o que se passa naquelas ruas: será um filme?

Teatro assumido como arte pública independente talvez seja a maior vertigem que o espetáculo desencadeia. Vi quando passageiros de um ônibus, bem como um caminhoneiro solitário, num cruzamento tríplice (Ruas Ribeiro Lima, Correia de Melo e da Graça), quase perderam o rumo ao serem despertados, pela luz e som, para a cena em que as atrizes Bia Bouissou e Laetitia Augustin-Viguier, esta também a guia impassível da peça, travam luta livre ao relento - e nuas.

Um taxista amigo, sr. Eder, que faz ponto no Bom Retiro, comentou de seu espanto quando surpreendeu, pela primeira vez, um dos ensaios do grupo, já entrando pela madrugada. "Pensei que fossem maloqueiros mesmo!..., disse, reportando a cena em que, pela Correia de Melo, desfilam catadores, cracômanos, agentes sanitários, carregadores, manequins, com seus coros, farrapos e lixos. "Desesperanto" é sua novilíngua, repetem alguns personagens, contracanto à utopia libertária internacionalista que o esperanto, projeto de língua franca, tentou representar para as levas de imigrantes e militantes, ainda no final dos Oitocentos.

Talvez essa pegada forte prescindisse de tanto apoio textual. Pois o que se acumulou nessas duas décadas como experiência mais ousada de criação cênica coletiva dirigida 
com talento inegável por Antônio Araújo refere-se à combinação bem concebida de locações insólitas com marcações decisivas de luz e som, em logística que reúne artesanato e tecnologia, tudo enfeixado por trabalho primoroso de expressão corporal em que o conjunto de atores supera-se a cada representação. Até aromas e fumaças atuam na produção sinestésica desses quadros tão contemporâneos em sua inatualidade.

Em ruínas. Uma linhagem de lugares arruinados pelo tempo dos homens vai se somando nas escolhas do Vertigem: o hospital Humberto Primo, em O Livro de Jó (1995); o presídio do Hipódromo, no impactante Apocalipse 1, 11 (2000); o fantasmagórico Rio Tietê, no BR-3 (2006), que sintetiza a desarmonia em três brasilidades agônicas como as de Brasília, Brasilândia e Brasileia; o espaço envidraçado de Kastelo (2010), motor do estranho-familiar que é o Kafka de cada dia; e os logradouros desse Bom Retiro ameaçado por Dibuk, que já se incorporou nas artérias do bairro e nas veias do corpo - do nosso corpo assustado por não ter como lembrar.

No espetáculo em cena, parece evidente que a dramaturgia de Joca Terron, ao privilegiar o antiquado registro supernaturalista, acaba produzindo excesso, tanto em tempo de falas quanto em overdose de brutalismo, o que se manifesta na relação do cracômano com sua pedra. Essa a vertigem mais óbvia, digamos. Outros núcleos dramáticos poderiam quem sabe obter melhor efeito cênico e crítico, como o das costureiras bolivianas invisíveis que, felizmente, retomam o fio de sua costura desesperançada antes do fim. $\mathrm{E}$ a encenação da última parte nesse edifício tão histórica e artisticamente pleno de significados que é o Taib (Teatro de Arte Israelita Brasileiro) - hoje teatro-fantasma - ganharia em agilidade e vigor se a incorporação do público à mecânica maldita do estranhamento não se arrastasse, ali, por tanto didatismo.

De todo modo, percorridos os 958 metros (quem se atreveria a conferir esse número?), o Teatro da Vertigem restitui-nos pedaços da memória social e cultural de um bairro, uma cidade, um país, ao revolver seus escombros, mas também os ícones da indústria-comércio de confecções têxteis, de que o Bom Retiro é polo nacional. Ironicamente, o início do passeio dá-se nesse shopping "coreano" à Rua Cesare Lombroso, cujo nome homenageia o famoso antropólogo-criminalista do século 19. Criador de teoria racialista biofísica entre as mais cientificamente admiradas em seu tempo, Lombroso legitimou biopolíticas de exclusão ao reforçar o trinômio raça/biótipo-loucura-crime contra populações como as dos despossuídos que começavam a constituir novo proletariado em São Paulo, inclusive nos cortiços do Bom Retiro. Assombroso, como sugere uma das placas reescritas na encenação. 
Mas ali é só a entrada do labirinto. Evacuados do Taib, da antiga Casa do Povo em que a comunidade judaica de esquerda fez história na cultura literária e teatral da segunda metade do século 20 , deparamos com uma caçamba, derradeiro palco em que as ótimas Mawusi Tulani (faxineira-filósofa e "modelo coreana certificada", com todo seu portentoso look africano) e Sofia Boito (manequim defeituosa em busca de emprego), que já tinham contracenado em dupla de área hilária, voltam a tecer, largadas como entulho, um diálogo idílico sobre as belezas da noite.

Os fantasmas, porém, teimam em açoitar sentimento e razão. Saindo dali, eu e uma amiga surpreendemos, quase meia-noite, na entrada de um daqueles antigos prédios baixos, ainda na Três Rios, uma senhorinha vestida impecavelmente, entrando em sua casa, acompanhada de uma moça, portando singelo ramalhete de flores. Seria a antiga guardiã do Taib? Ainda uma atriz desavisada do fim da sessão? Era real essa anciã, remanescente dos antigos narradores de Dibuk? Ou ela própria aparição de todas as nossas desculpas?

Claro está que ninguém saberá. Fiquemos por ora com a noite fria e vital dos sinais de perigo de Bom Retiro 958 metros. Quem sabe a última palavra se converta em pedra, como desejava a infatigável consumidora (Luciana Schwinden), e as portas de todas as lojas se escancarem, em explosão lúdica e fulminante. E com ela a lei vire letra comum. E a história, memória comungada nos corpos. E a vertigem, esta que a magia da ribalta nos passa, seja apenas o silêncio que a lua e o vento saberão dispor. 